\title{
Culture study on the hybrid by interspecific crossing between Porphyra pseudolinearis and P. dentata (Bangiales, Rhodophyta), two dioecious species in culture
}

\author{
Nam-Gil Kim ${ }^{1, *}$ \\ ${ }^{1}$ Department of Marine Biology and Aquaculture / Institute of Marine Industry, Gyeongsang National University, \\ Tongyeong 650-160, Korea
}

Physiological studies on the hybrid by crossing between two dioecious species, Porphyra pseudolinearis and P. dentata from Korea were conducted at constant temperatures $\left(5,10,15,20\right.$, and $\left.25^{\circ} \mathrm{C}\right)$, at photon flux densities $(10,20,40$, and $80 \mu \mathrm{mol} \mathrm{m}^{-2} \mathrm{~s}^{-1}$ ) under photoperiods (14 L : $10 \mathrm{D}$ and $\left.10 \mathrm{~L}: 14 \mathrm{D}\right)$. In the hybrid, higher growth of conchocelis was observed at 20 and $40 \mu \mathrm{mol} \mathrm{m}^{-2} \mathrm{~s}^{-1}$ under $14 \mathrm{~L}: 10 \mathrm{D}$. Conchosporangial branches were produced under 10-80 $\mu \mathrm{mol} \mathrm{m}^{-2} \mathrm{~s}^{-1}$ at only $25^{\circ} \mathrm{C}$, and were abundant when the conchocelis was cultured under $10 \mathrm{~L}: 14 \mathrm{D}$. Foliose thalli of the hybrid grew well at the conditions of $10-20^{\circ} \mathrm{C}, 10 \mathrm{~L}: 14 \mathrm{D}$ and $15-20^{\circ} \mathrm{C}, 14 \mathrm{~L}: 10 \mathrm{D}$. The foliose thalli grew very slowly at $5^{\circ} \mathrm{C}$ and $30^{\circ} \mathrm{C}$, respectively. No archeospores were observed at any culture conditions. Spermatangial and zygotosporangial sori were formed at the marginal portion of mature thallus. Zygotospores from the hybrid were released at $10-20^{\circ} \mathrm{C}$ under both photoperiods, and gave rise to form conchocelis filament. Monoecious thalli were observed at $10^{\circ} \mathrm{C}$ under $14 \mathrm{~L}: 10 \mathrm{D}$. Neither monospores nor protothalli were produced from the conchocelis in culture.

Key Words: Bangiales; hybrid; interspecific crossing; physiology; Porphyra dentata; Porphyra pseudolinearis; Rhodophyta

\section{INTRODUCTION}

Porphyra dentata and P. pseudolinearis, originally described from Japan (Ueda 1932) were recorded in a checklist of marine algae from Korea by Lee and Kang (1986). Porphyra dentata is widely distributed in warm temperate waters (Ueda 1932, Tseng 1948, Tanaka 1952, Kim 1999), whereas P. pseudolinearis is found in cold temperate waters of the North Pacific (Ueda 1932, Tanaka 1952, Kang 1966, Wynne 1972, Scagel et al. 1989, Lindstrom and Cole 1992, 1993, Kim 1999). At present, P. dentata and $P$. pseudolinearis as the cultivars are crops of the most economical importance to inhabitants along the southern and eastern coast of Korea, respectively and one of the popular Korean marine products. Especially, they are famous for Dolkim (in Korean, meaning of Porphyra growing on the rocky beds in nature). Until now, the cultivated plants are mainly P. tenera and P. yezoensis in Korea (Kim 1999). However, both species are cheaper than the other cultivars (e.g., $P$. dentata, $P$. pseudolinearis and $P$. seriata). Therefore, the cultivation of $P$. dentata and P. pseudolinearis are very important for the seaweed farmer of Korea. But there are some problems in the farming periods of the both species. The cultivation of $P$. dentata is limited in higher temperature periods (from September to November), while that of $P$. pseudolinearis is limited in low- (c) This is an Open Access article distributed under the terms of the Creative Commons Attribution Non-Commercial License (http://creativecommons.org/licenses/by-nc/3.0/) which permits unrestricted non-commercial use, distribution, and reproduction in any medium, provided the original work is properly cited.
Received 30 November 2010, Accepted 26 February 2011

* Corresponding Author

E-mail: ngkim@gnu.ac.kr

Tel: +82-55-772-9155 Fax: +82-55-642-4509 
er temperature periods (from December to February). Therefore, seaweed farmers has need for prolongation the farming period of both valuable species in Korea.

Studies on the crossing of Porphyra have been completed in laboratory culture (Suto 1963, Niwa et al. 1993, Shin and Miura 1995, Shin et al. 1996, Shin 1999).

Suto (1963) attempted artificial cross experiments between 5 species including two monoecious (e.g., P. tenera and P. yezoensis) and three dioecious (e.g., P. angusta, $P$. pseudolinearis and P. umbilicalis). Shin and Miura (1995), Shin et al. (1996) and Shin (1999) succeeded in interspecific crossing between $P$. tenera and $P$. yezoensis using their color mutants as genetic markers. Ohme and Miura (1988) and Niwa et al. (1993) reported intraspecific crossing between wild-type and various color mutants of P. yezoensis.

I have been conducting cross experiments between $P$. dentata and P. pseudolinearis using their field materials as new cultivars for characteristic tests and physiological identification of the hybrid as a part of breeding studies of both species. In present study, the results of interspecific crossing between P. dentata and P. pseudolinearis are reported.

\section{MATERIALS AND METHODS}

Mature foliose thalli of $P$. dentata and P. pseudolinearis were collected from the upper intertidal zone at Wando in Chonnam Prefecture, and Pohang in Gyeongbuk prefecture, on 11 and 28 February 1996, respectively (Kim 1999). From these thalli, zygotospores were obtained to start conchocelis cultures. Conchospore liberation in both species was induced by reducing the temperature from 20 to $15^{\circ} \mathrm{C}$. The resulting foliose thalli were transferred into round flasks. Cultures were separately conducted by the use of one plant per a flask. The artificial crossing was conducted by using the male thalli of P. pseudolinearis and female thalli of $P$. dentata. Zygotospores from hybrid were cultured at five temperatures $(5,10,15,20$, and $\left.25^{\circ} \mathrm{C}\right)$ and four photon flux densities $(10,20,40$, and $\left.80 \mu \mathrm{mol} \mathrm{m}^{-2} \mathrm{~s}^{-1}\right)$ under photoperiods of $14 \mathrm{~L}: 10 \mathrm{D}$ and $10 \mathrm{~L}$ : $14 \mathrm{D}$ (light : dark). The growth of conchocelis was determined by measuring the diameter of colonies at weekly intervals. Conchospore liberation from matured conchosporangial branches was induced by reducing the temperature from 25 to $15^{\circ} \mathrm{C}$. The resulting foliose thalli were cultured at five temperatures $\left(5,10,15,20\right.$, and $\left.25^{\circ} \mathrm{C}\right)$ and $40 \mu \mathrm{mol} \mathrm{m}{ }^{-2} \mathrm{~s}^{-1}$ under photoperiods of $14 \mathrm{~L}: 10 \mathrm{D}$ and 10 $\mathrm{L}: 14 \mathrm{D}$ in $300 \mathrm{~mL}$ round flask with an air tube. Growth was determined from measurements of blade length and width. Modified Grund medium (McLachlan 1973) was used in all cultures and was renewed weekly.

\section{RESULTS}

Zygotospores from the hybrid by interspecific crossing between both species were germinated to the conchocelis filaments at $5-25^{\circ} \mathrm{C}$ (Fig. 1A \& B). Conchocelis filaments grew to a colony of about $1.5 \mathrm{~mm}$ diameter at $20^{\circ} \mathrm{C}$ after 3 weeks (Fig. 1C). The conchosporangial branches were produced only from the conchocelis colonies grown at $25^{\circ} \mathrm{C}$ under both photoperiods (Fig. 1D). Conchospores liberated from the conchosporangial branch were well developed to four cells sporeling (ca. $40 \mu \mathrm{m}$ long) after 3 days (Fig. 1E \& F). Archeospores did not liberate from foliose thalli. Male and female reproductive organs began to occur in the marginal parts of plants, about 10 $\mathrm{mm}$ long after 8 weeks at $15^{\circ} \mathrm{C}$ and $40 \mu \mathrm{mol} \mathrm{m} \mathrm{m}^{-2} \mathrm{~s}^{-1}$ under 14 L : 10 D (Fig. 1G \& H). Mature spermatangia had a Hus's (1902) fomula $64,(a / 4, b / 4, c / 4)$ or $128,(a / 4, b / 4$, c/8) (Fig. 1G \& I). The zygotosporangia contained 8 zygotospores formed by the division pattern $(\mathrm{a} / 2, \mathrm{~b} / 2, \mathrm{c} / 2)$ (Fig. $1 \mathrm{H} \& \mathrm{~J}$ ). The marginal portions of fronds were entire or micro and macroscopic spinulate processes (Fig. 1K \& L). The basal portion of frond has the more clear spinulate processes (Fig. 1M). The largest thalli were obtained at $10-20^{\circ} \mathrm{C}$ under both photoperiods after 18 weeks in culture. These foliose thalli reached to a blade length of about $130 \mathrm{~mm}$ under the long photoperiod, and of about $190 \mathrm{~mm}$ under the short photoperiod after 14 weeks. The shape of foliose thalli were linear or lanceolate types (Fig. $1 \mathrm{~N} \& \mathrm{O})$. The zygotospores produced either monoecious thalli (Fig. 1P) or dioecious thalli.

\section{Growth of the Sporophyte (conchocelis) phase}

The zygotospores of hybrid were germinated into the conchocelis colonies at $5-25^{\circ} \mathrm{C}$ and four photon flux densities under both photoperiods. Higher growth of conchocelis was observed at 15 and $20^{\circ} \mathrm{C}$ under both photoperiods (Fig. 2). There were no remarkable differences in the growth of conchocelis according to photon flux densities. The maximum diameter of conchocelis colonies was about $2.5 \mathrm{~mm}$ within 10 weeks.

Formation rates of conchosporangial branches at different combinations of temperature and photon flux density are presented in Fig. 3. Conchocelis colonies with conchosporangial branches were produced only at $25^{\circ} \mathrm{C}$ 


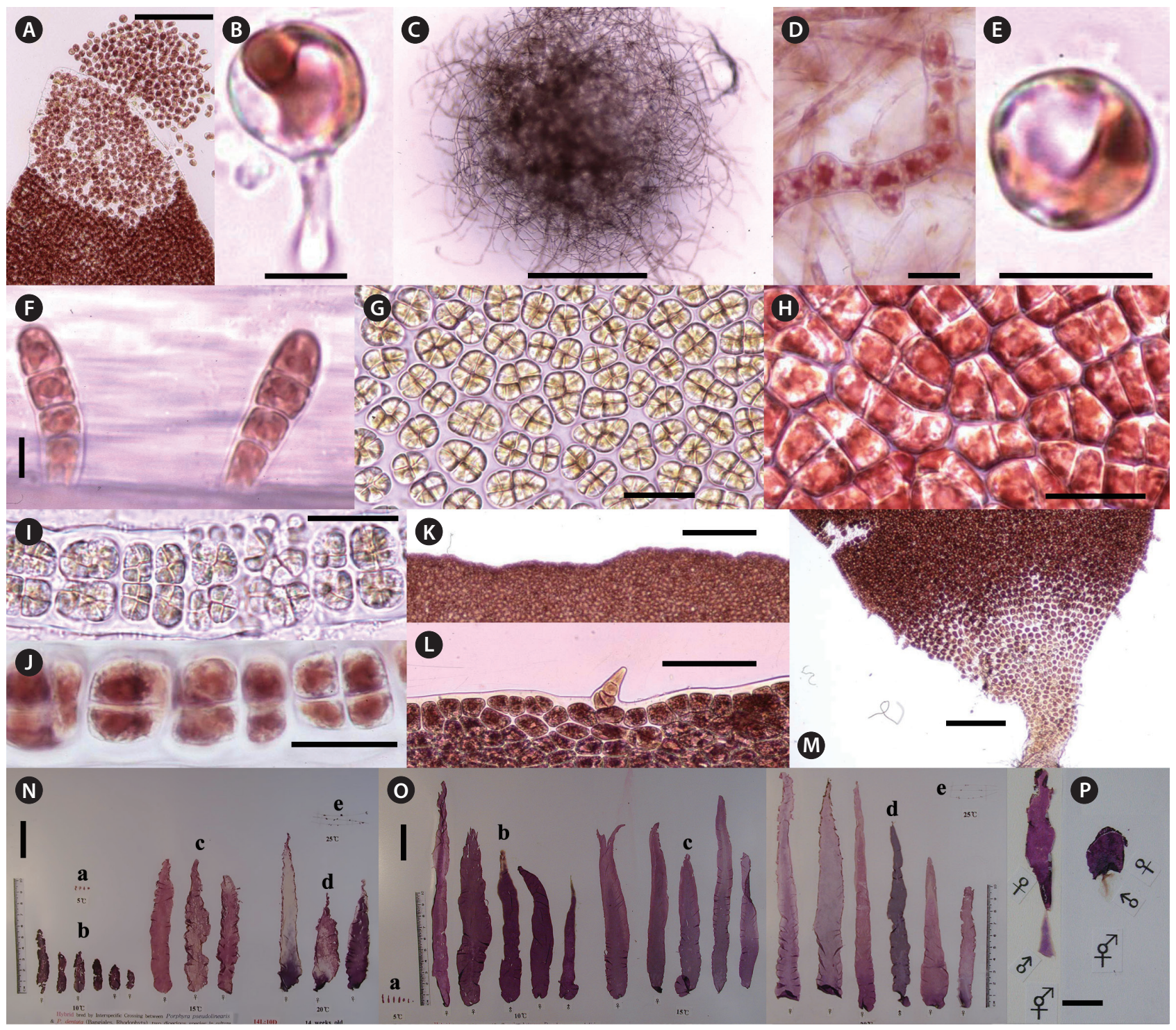

Fig. 1. Life history of hybrid by crossing between Porphyra pseudolinearis and P. dentata. (A) Zygotospores liberating from mature hybrid foliose thallus by crossing between Porphyra pseudolinearis and P. dentata in culture. (B) Germinating spore showing developing conchocelis from zygotospore. (C) Free-living conchocelis colony grown at $20^{\circ} \mathrm{C}$ and $80 \mu \mathrm{mol} \mathrm{m} \mathrm{s}^{-1}$ under $14 \mathrm{~L}: 10 \mathrm{D}$. (D) Conchosporangial branch after 3 weeks at $25^{\circ} \mathrm{C}$ and $40 \mu \mathrm{mol} \mathrm{m}^{-2} \mathrm{~s}^{-1}$ under $10 \mathrm{~L}: 14 \mathrm{D}$. (E) Conchospore liberated from conchosporangia. (F) Sporlings germinated from conchospore. (G) Surface view of spermatangia. (H) Surface view of zygotosporangia. (I) Spermatangia in cross-section. (J) Zygotosporangia in cross-section. (K) Entire marginal part of hybrid foliose thallus. (L) Marginal portion of frond showing an only microscopic spinulate process. (M) Basal part of young foliose thallus with microscopic spinulate processes. ( $N$ \& O) Foliose thalli of 15 weeks old grown in culture showing different thallus shapes under $14 \mathrm{~L}$ : $10 \mathrm{D}(\mathrm{N})$ and $10 \mathrm{~L}: 14 \mathrm{D}(\mathrm{O})$, respectively; (a) $5^{\circ} \mathrm{C}$, (b) $10^{\circ} \mathrm{C}$, (c) $15^{\circ} \mathrm{C}$, (d) $20^{\circ} \mathrm{C}$, (e) $25^{\circ} \mathrm{C}$. (P) Monoecious thalli after 10 weeks at $10^{\circ} \mathrm{C}$ and $40 \mu \mathrm{mol} \mathrm{m}^{-2}$ $\mathrm{s}^{-1}$ under $14 \mathrm{~L}: 10 \mathrm{D}$. Scale bars represent: $A, 10 \mathrm{~mm} ; \mathrm{B}, \mathrm{D} \& \mathrm{~L}, 5 \mu \mathrm{m} ; \mathrm{C}, 50 \mu \mathrm{m} ; \mathrm{E} \& \mathrm{~F}, 10 \mu \mathrm{m} ; \mathrm{G}-\mathrm{K} \& \mathrm{M}, 20 \mu \mathrm{m} ; \mathrm{N}$ \& O, $30 \mathrm{~mm} ; \mathrm{P}, 10 \mathrm{~mm}$.

and 10-80 $\mu \mathrm{mol} \mathrm{m} \mathrm{m}^{-2} \mathrm{~s}^{-1}$ under both photoperiods within 3 weeks. Formation rates of conchosporangial branches reached $100 \%$ within 10 weeks. Conchospores did not liberate at any culture conditions.

\section{Growth and maturation of the gametophyte phase}

Liberation of conchospores in hybrid species was obtained by reducing the temperature from 25 to $15^{\circ} \mathrm{C}$. Growth of foliose thalli at various temperatures under both photoperiods are shown in Fig. 4. Germlings of the hybrid reached their largest size, about $19 \mathrm{~cm}$ long at $20^{\circ} \mathrm{C}$ under short photoperiod after 14 weeks in cul- 


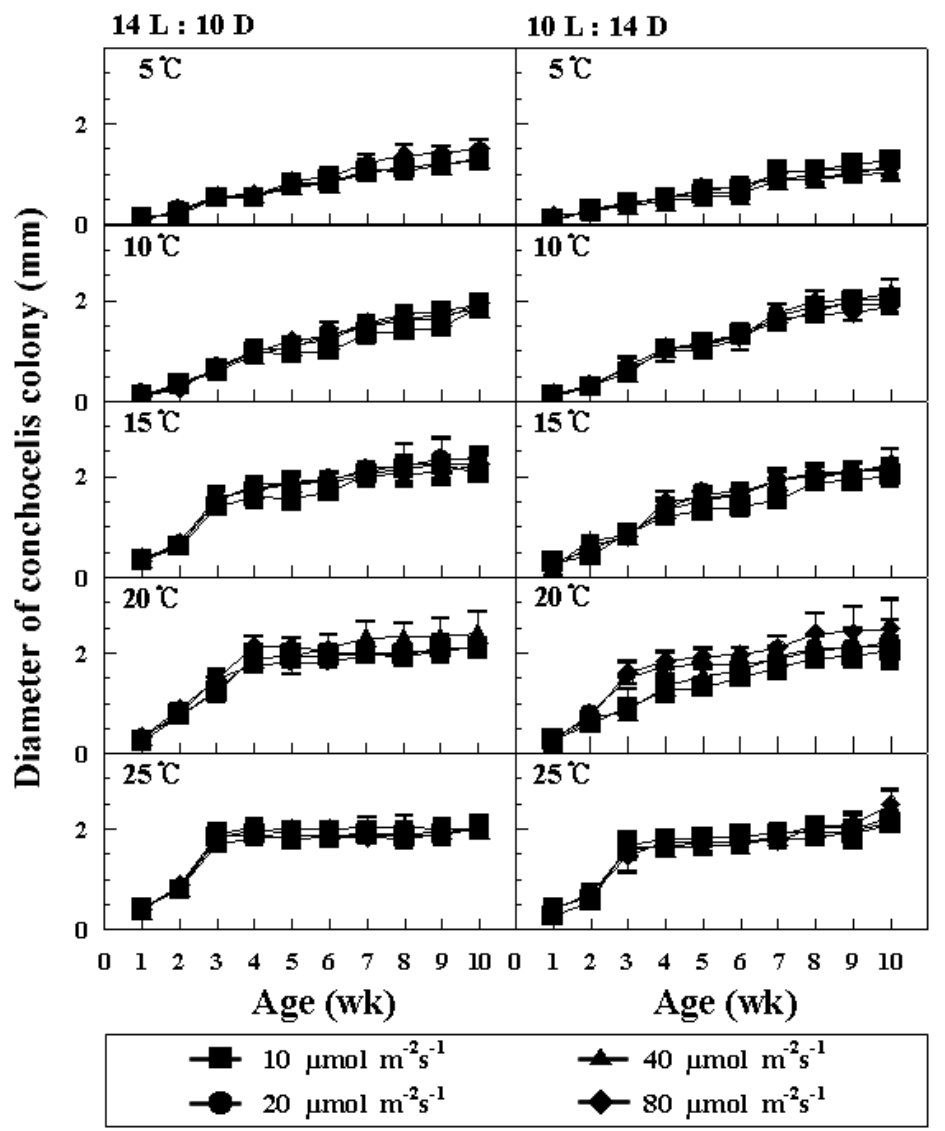

Fig. 2. Growth of hybrid conchocelis colonies by crossing between Porphyra pseudolinearis and $P$. dentata at five temperatures $\left(5-25^{\circ} \mathrm{C}\right)$ and photon flux densities $\left(10-80 \mu \mathrm{mol} \mathrm{m}^{-2} \mathrm{~s}^{-1}\right)$ under $14 \mathrm{~L}: 10 \mathrm{D}$ and $10 \mathrm{~L}: 14 \mathrm{D}$. Vertical bars are standard deviations.

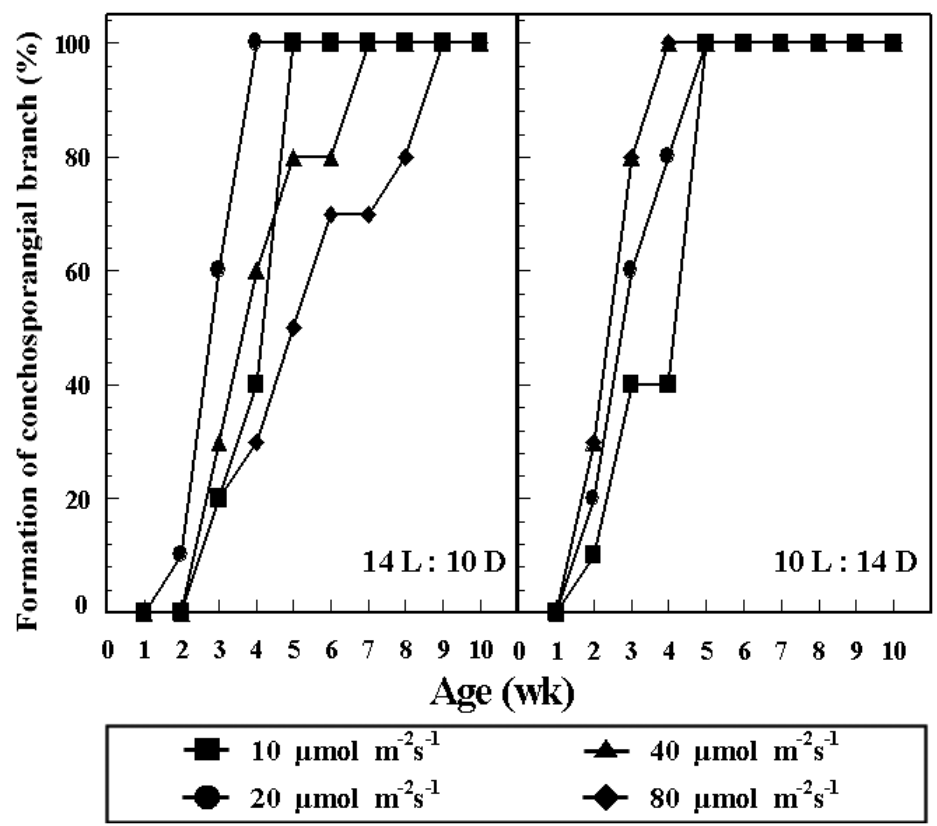

Fig. 3. Formation rates of conchosporangial branch by crossing between Porphyra pseudolinearis and $P$. dentata at $25^{\circ} \mathrm{C}$ and photon flux densities $\left(10-80 \mu \mathrm{mol} \mathrm{m}^{-2} \mathrm{~s}^{-1}\right)$ under $14 \mathrm{~L}: 10 \mathrm{D}$ and $10 \mathrm{~L}: 14 \mathrm{D}$. Percentage of conchocelis colonies with conchosporangial branches. 


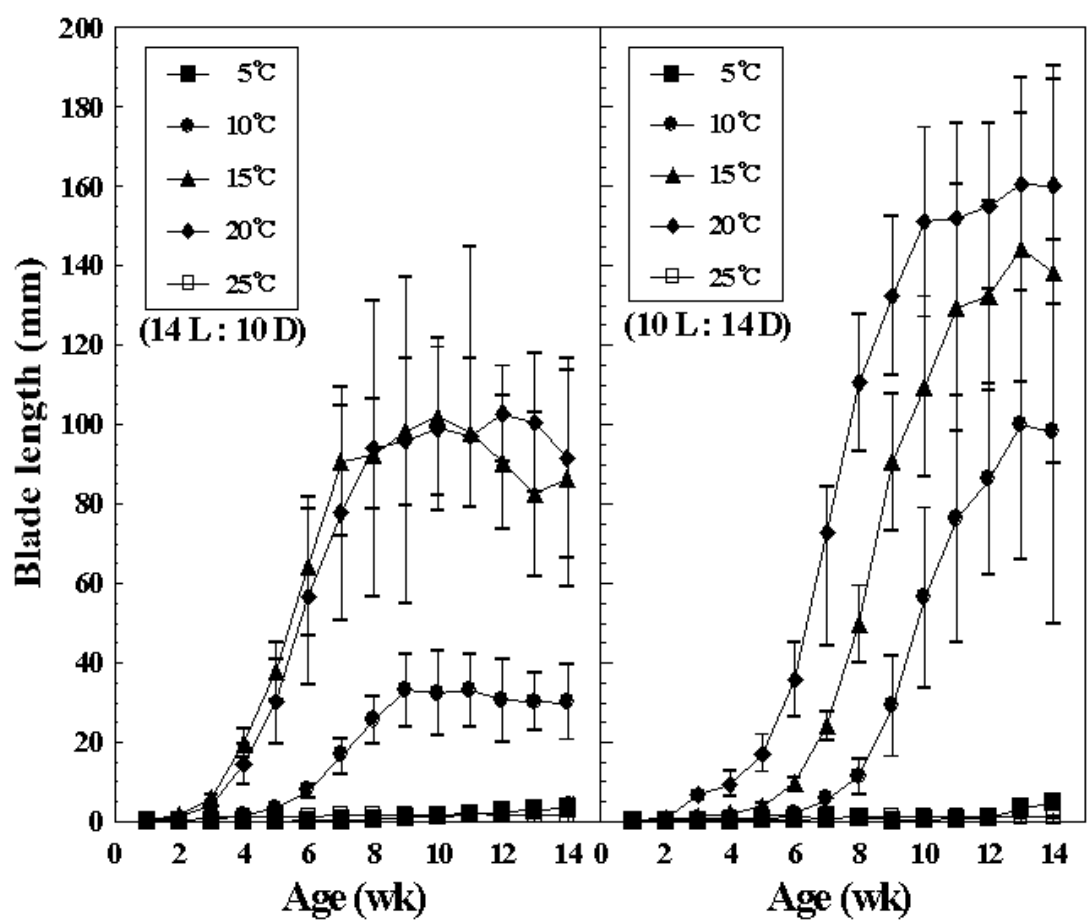

Fig. 4. Growth of hybrid foliose thallus by crossing between Porphyra pseudolinearis and $P$. dentata at five temperatures $\left(5-25^{\circ} \mathrm{C}\right)$ and $40 \mu \mathrm{mol}$ $\mathrm{m}^{-2} \mathrm{~s}^{-1}$ under $14 \mathrm{~L}: 10 \mathrm{D}$ and $10 \mathrm{~L}: 14 \mathrm{D}$. Vertical bars are standard deviations.

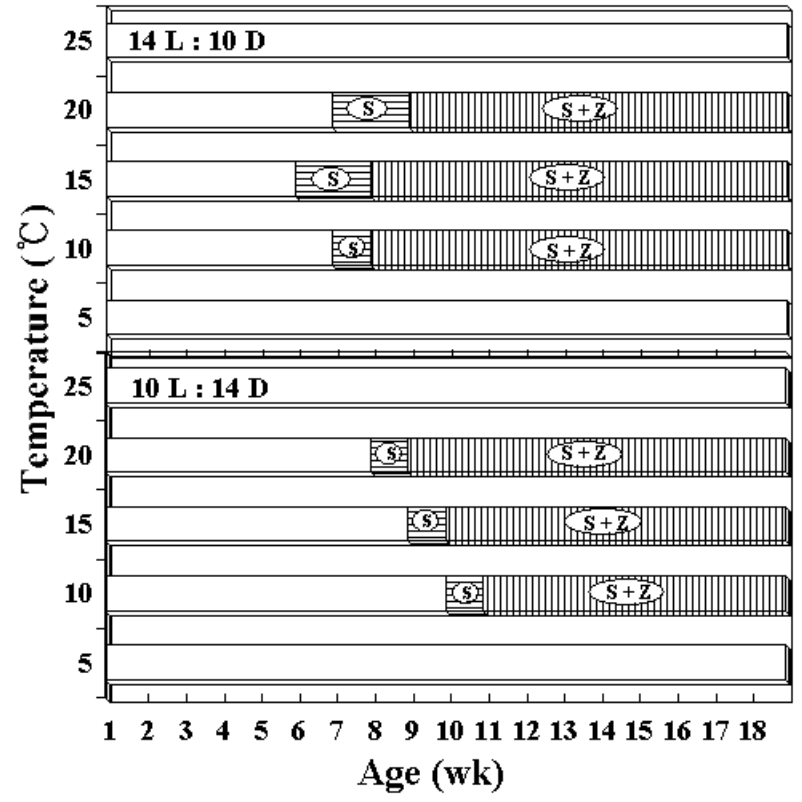

Fig. 5. Liberation of spermatia and zygotospores in relation to the age of cultured hybrid foliose thallus by crossing between Porphyra pseudolinearis and $P$. dentata at five temperatures $\left(5-25^{\circ} \mathrm{C}\right)$ and $40 \mu \mathrm{mol} \mathrm{m} \mathrm{m}^{-2}$ under $14 \mathrm{~L}: 10 \mathrm{D}$ and $10 \mathrm{~L}: 14 \mathrm{D}$. Open space bars, neither spermatia nor zygotospores liberated; horizontal stripe space, spermatia liberated; vertical stripe space, spermatia and zygotospores liberated; $\mathrm{S}$ and $\mathrm{Z}$ refer to spermatia and zygotospores, respectively. ture, whereas initially thalli grew faster $15^{\circ} \mathrm{C}$ under long photoperiods. At 5 and $25^{\circ} \mathrm{C}$, foliose thalli showed almost no growth. They grew to $10 \mathrm{~mm}$ or under in blade length during the culture period. The liberation of spermatia and zygotospores at various temperatures and both photoperiods is presented in Fig. 5. In this hybrid species, archeospores did not liberate in all culture conditions. Their liberation occured at 10 and $20^{\circ} \mathrm{C}$ under both photoperiods within 11 weeks. The linear or lanceolate shape of fronds, similar to that in nature, was observed under culture conditions that produced rapid growth (Fig. 6).

\section{DISCUSSION}

Hybrid shows a typical biphasic life history of the $P$. lacerata type (Notoya et al. 1993). Zygotospores mostly developed into conchocelis colonies in all culture conditions. Conchosporangial branches were produced at $25^{\circ} \mathrm{C}$ only and $10-80 \mu \mathrm{mol} \mathrm{m}^{-2} \mathrm{~s}^{-1}$ under both photoperiods. Kim (1999) reported that zygotospores of P. dentata and $P$. pseudolinearis were germinated into conchocelis colonies and conchosporangial branches were produced at $10-25^{\circ} \mathrm{C}, 10-80 \mu \mathrm{mol} \mathrm{m}^{-2} \mathrm{~s}^{-1}$ under short photoperiod. Kim (1999) also reported that formation rates of concho- 


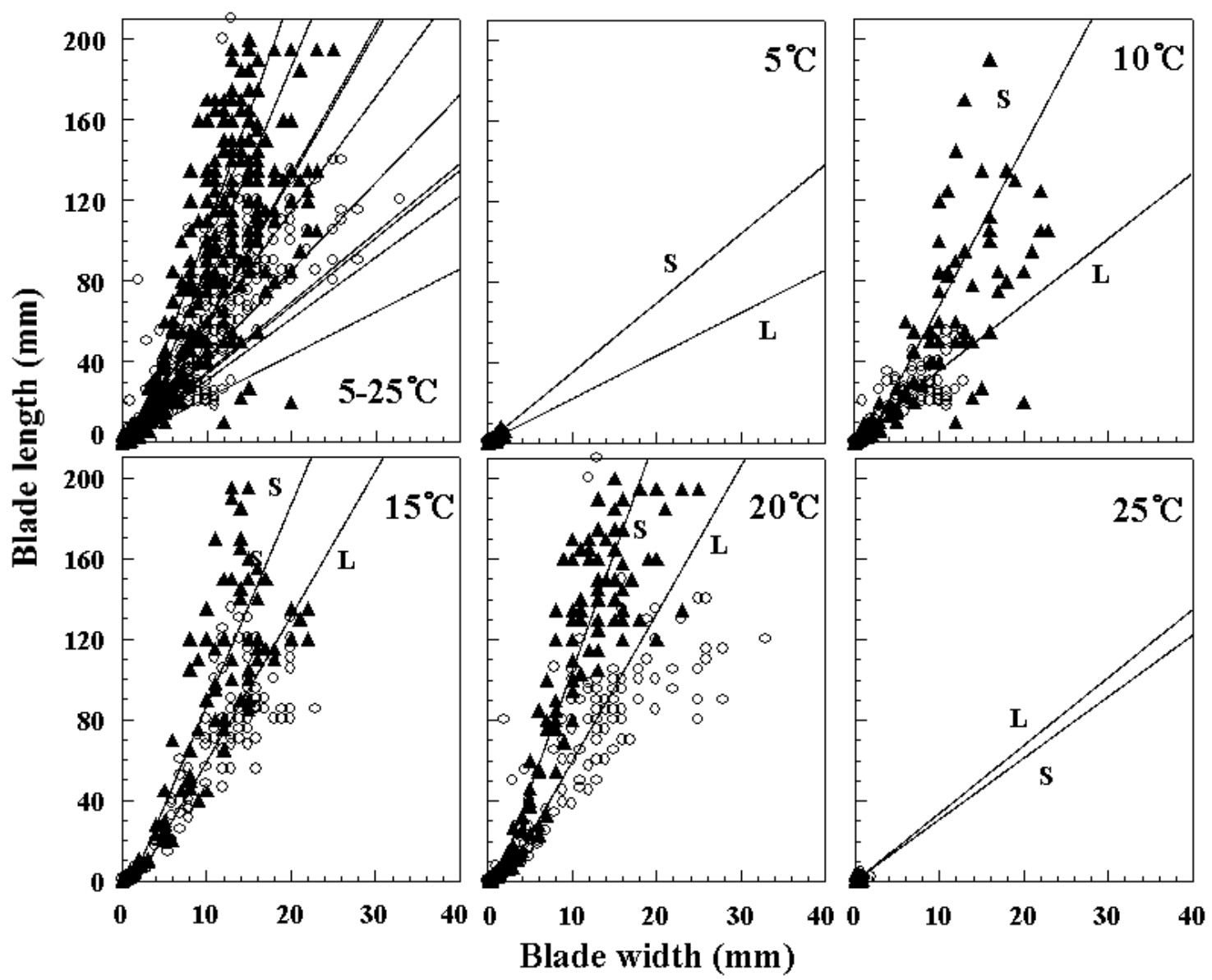

Fig. 6. Relationship between blade length and width in hybrid by crossing between Porphyra pseudolinearis and $P$. dentata at five temperatures $\left(5-25^{\circ} \mathrm{C}\right)$ and $40 \mu \mathrm{mol} \mathrm{m}^{-2} \mathrm{~s}^{-1}$ under $14 \mathrm{~L}: 10 \mathrm{D}$ and $10 \mathrm{~L}: 14 \mathrm{D}$. Solid triangles are $14 \mathrm{~L}: 10 \mathrm{D}(\mathrm{L})$; open circles are $10 \mathrm{~L}: 14 \mathrm{D}(\mathrm{S})$.

sporangia in two species were higher at high temperatures than at low temperatures. This result suggests that the abundance of conchosporangial branches in hybrid were also affected by high temperature (Kurogi and Akiyama 1966). Conchospore liberation in this species was induced by reducing temperature from 25 to $15^{\circ} \mathrm{C}$ (Kurogi and Akiyama 1966, Iwasaki and Sasaki 1971) and changing photoperiod from $14 \mathrm{~L}$ : $10 \mathrm{D}$ to $10 \mathrm{~L}$ : $14 \mathrm{D}$ (Kim 1999). In other species for Porphyra such as, P. abbottae and $P$. perforata (Waaland and Dickson 1983) and $P$. rosengurtii (Kapraun and Luster 1980) require a photoperiodic change to induce spore liberation (Waaland et al. 1990). Our results agree well with those reported on P. suborbiculata f. latifolia by Iwasaki and Sasaki (1971), on P. columbina by Avila et al. (1986) and on P. spiralis var. amplifolia by Kapraun and Lemus (1987).

Notoya et al. (1993) studied four species of Japanese Porphyra, including $P$. dentata. They reported that conchosporangial branches were formed at a temperature range of 20 to $25^{\circ} \mathrm{C}$, and the fast growth of foliose thalli occured at $20^{\circ} \mathrm{C}$ in P. dentata. Our results well agree with their results with respect to growth and maturation of both phase which are observed at various temperatures and photon flux densities. P. dentata widely distributed on intertidal zone in the warm, temperate and cold waters (Ueda 1932, Tseng 1948, Kim 1999). Kim (1999) reported that in $P$. pseudolinearis, the growth of conchocelis and the formation of conchosporangial branches occured at $5-25^{\circ} \mathrm{C}$ and $10-25^{\circ} \mathrm{C}$ under all the photon flux densities tested, respectively. Kurogi and Akiyama (1966) and Iwasaki and Sasaki (1971) reported that conchosporangial branches were formed at 15 to $25^{\circ} \mathrm{C}$ or $27^{\circ} \mathrm{C}$ in all the species studied.

Kim (1999) reported that the growth of foliose thalli, in P. pseudolinearis and P. dentata was fast at $15^{\circ} \mathrm{C}$ in early developmental stage. Generally, P. pseudolinearis is distributed in temperate and cold water regions (Tanaka 1952, Kang 1966, Wynne 1972, Perestenko 1982, Scagel et 
al. 1989, Lindstrom and Cole 1992, 1993).

He also reported that $P$. pseudolinearis showed almost no growth at $25^{\circ} \mathrm{C}$ while the blade length of $P$. dentata did not increase at $5^{\circ} \mathrm{C}$ for 10 weeks. Our results suggest that hybrid will grow at wide range $\left(10-20^{\circ} \mathrm{C}\right)$ temperatures.

The young thallus with denticulate marginal cell rows was observed at $10^{\circ} \mathrm{C}$ at first, and it was quickly produced at low temperatures than high temperatures. In this study, the monoecious foliose thalli sectored by horizontal line were produced at $10^{\circ} \mathrm{C}$ and $10 \mathrm{~L}: 14 \mathrm{D}$. Hitherto, some authors (Chang and Zheng 1960, Lindstrom and Cole 1992, 1993) reported dioecious Porphyra species with monoecious plants for $P$. haitanensis, $P$. lanceolata, $P$. pseudolanceolata, P. linearis, P. mumfordii, P. lanceolata, P. pseudolinearis and P. purpurea.

P. dentata and P. pseudolinearis are typical dioecious species (Tanaka 1952), but monoecious plants were reported by Hwang (1994) in field and culture observations from Japan and Korea, respectively.

No archeospores were produced under any culture conditions in hybrid species, and neither monospores nor protothalli were produced from the conchocelis phase.

In the anatomical examination of the hybrid, the divisional formulas of spermatangia according to Hus (1902) well agree with those of Tanaka (1952) but zygotosporangia did not.

Based on the results of this study and previous reports of two species in culture (Kurogi and Akiyama 1966, Notoya et al. 1993) and field investigation (Kang 1966, Wynne 1972, Scagel et al. 1989, Lindstrom and Cole 1992), the temperature needed for the growth and maturation of both phases of hybrid falls between low and high temperatures.

In conclusion, these culture studies indicate that the growth and maturation of both the foliose and conchocelis phase of the hybrid are more influenced by temperature than photon irradiance. Furthermore, it is apparent that the hybrid has monoecious and dioecious thalli, and suggests that hybrid more can be eurythermal cultivar than two cultivars, P. dentata and P. pseudolinearis.

\section{REFERENCES}

Avila, M., Santelices, B. \& McLachlan, J. 1986. Photoperiod and temperature regulation of the life history of Porphyra columbina (Rhodophyta, Bangiales) from central Chile. Can. J. Bot. 64:1867-1872.

Chang, T. \& Zheng, B. 1960. Porphyra haitanensis, a new spe- cies of Porphyra from Fukien. Acta Bot. Sin. 9:32-36.

Hus, H. T. A. 1902. An account of the species of Porphyra found on the pacific coast of north America. Proc. Calif. Acad. Sci. 3rd Ser. Bot. 2:173-241.

Hwang, M. S. 1994. Taxonomic studies of genus Porphyra of Korea. Ph. D. dissertation, Seoul National University, Seoul, Korea, 277 pp. (in Korean with English abstract).

Iwasaki, H. \& Sasaki, N. 1971. The conchocelis-phase of Porphyra suborbiculata forma latifolia. Proc. Int. Seaweed Symp. 7:364-367.

Kang, J. W. 1966. On the geographical distribution of marine algae in Korea. Bull. Pusan Fish. Coll. 7:1-125.

Kapraun, D. F. \& Lemus, A. J. 1987. Field and culture studies of Porphyra spiralis var. amplifolia Oliveira Filho et Coll (Bangiales, Rhodophyta) from Isla de Margarita, Venezuela. Bot. Mar. 30:483-490.

Kapraun, D. F. \& Luster, D. G. 1980. Field and culture studies of Porphyra rosengurtii Coll et Cox (Rhodophyta, Bangiales) from North Carolina. Bot. Mar. 23:449-457.

Kim, N. G. 1999. Culture studies of Porphyra dentata and $P$. pseudolinearis (Bangiales, Rhodophyta), two dioecious species from Korea. Hydrobiologia 398/399:127-135.

Kurogi, M. \& Akiyama, K. 1966. Effects of water temperature on the growth and maturation of conchocelis-thallus in several species of Porphyra. Bull. Tohoku Reg. Fish. Res. Lab. 26:77-89 (in Japanese with English abstract).

Lee, I. K. \& Kang, J. W. 1986. A check list of marine algae in Korea. Korean J. Phycol. 1:311-325.

Lindstrom, S. C. \& Cole, K. M. 1992. A revision of the species of Porphyra (Rhodophyta: Bangiales) occurring in British Columbia and adjacent waters. Can. J. Bot. 70:20662075.

Lindstrom, S. C. \& Cole, K. M. 1993. The systematics of Porphyra: character evolution in closely related species. Hydrobiologia 260/261:151-157.

McLachlan, J. 1973. Growth media-marine. In Stein, J. R. (Ed.) Handbook of Phycological Methods: Culture Methods Growth Measurements. Cambridge University Press, New York, pp. 25-51.

Niwa, K., Miura, A., Shin, J. -A. \& Aruga, Y. 1993. Characterization and genetic analysis of the violet type pigmentation mutant of Porphyra yezoensis Ueda (Bangiales, Rhodophyta). Korean J. Phycol. 8:217-230.

Notoya, M., Kikuchi, N., Matsuo, M., Aruga, Y. \& Miura, A. 1993. Culture studies of four species of Porphyra (Rhodophyta) from Japan. Nippon Suisan Gakkaishi 59:431436.

Ohme, M. \& Miura, A. 1988. Tetrad analysis in conchospore germlings of Porphyra yezoensis (Rhodophyta, Bangiales). Plant Sci. 57:135-140. 
Perestenko, L. P. 1982. Species generis Porphyra Ag. in Maribus orientaris extremi URSS. I. Novitates systematicae plantarum non vascularium tomus, 19:16-29 (in Russian).

Scagel, R. F., Gabrielson, P. W., Garbary, D. J., Golden, L., Hawkes, M. W., Lindstrom, S. C., Oliveira, J. C. \& Widdowson, T. B. 1989. A synopsis of the benthic marine algae of British Columbia, Southeast Alaska, Washington and Oregon: phycological contribution 3. University of British Columbia, Vancouver, 532 pp.

Shin, J. -A. 1999. Crossing between Porphyra yezoensis and $P$. tenera. Algae 14:73-77.

Shin, J. A. \& Miura, A. 1995. Contents of alanine and glutamic acid in the new variety bred by interspecific crossing between Porphyra tenera and P. yezoensis (Bangiales, Rhodophyta). J. Aomori Univ. Aomori Jr. Coll. 18:95-100.

Shin, J. -A., Nishimoto, H. \& Miura, A. 1996. Contents of photosynthetic pigments in a new cultivar bred by interspecific crossing between Porphyra tenera and P. yezoensis (Bangiales, Rhodophyta): preliminary report. Algae
11:389-390.

Suto, S. 1963. Intergeneric and interspecific crossings of the lavers (Porphyra). Bull. Fish. Jpn. Soc. Sci. Fish. 29:739748.

Tanaka, T. 1952. The systematic study of the Japanese Protoflorideae. Mem. Fac. Fish. Kagoshima Univ. 2:1-92.

Tseng, C. K. 1948. Marine algae of Hongkong 7: the order Bangiales. Lingnan Sci. J. 22:121-131.

Ueda, S. 1932. Taxonomic studies on the Japanese Porphyra. J. Imp. Fish. Inst. 28:1-45 (in Japanese).

Waaland, J. R. \& Dickson, L. G. 1983. Photoperiodic control of conchospore maturation and release in Porphyra abbottae and Porphyra perforata Rhodophyta. J. Phycol. 19(Suppl.):6.

Waaland, J. R., Dickson, L. G. \& Duffield, E. C. S. 1990. Conchospore production and seasonal occurrence of some Porphyra species (Bangiales, Rhodophyta) in Washington State. Hydrobiologia 204/205:453-459.

Wynne, M. J. 1972. The genus Porphyra at Amchitka island, Aleutians. Proc. Int. Seaweed Symp. 7:100-104. 